\title{
ARID4B wt Allele
}

National Cancer Institute

\section{Source}

National Cancer Institute. ARID4B wt Allele. NCI Thesaurus. Code C51104.

Human ARID4B wild-type allele is located within 1q42.1-q43 and is approximately $196 \mathrm{~kb}$ in length. This allele, which encodes AT-rich interactive domain-containing protein 4B protein, is involved in DNA binding. 